\title{
Euphemisms in Japanese:
}

a Study of Some Thematic Fields

\author{
Olimpiada F. Ivanova and Elena V. Anashkina* \\ National Research University Higher School of Economics (HSE) \\ 20 Myasnitskaya, Moscow, 101000, Russia
}

Received 29.12.2014, received in revised form 05.01.2015, accepted 11.08.2015

\begin{abstract}
The subject of this article is the results of a pilot research of Japanese euphemisms conducted at Hokkaido University, Japan. Japanese euphemisms remain a low-studied layer of lexis. The aim of the article is to analyze the euphemisms used by the Japanese in such thematic fields as low intelligence, physically challenged people, ugly appearance, serious diseases, death and low social status and to define the most frequently used ways of making Japanese euphemisms. The results of the research may be helpful for those who study Japanese language and culture and want to understand their nuances better. Also, the article may help translators find efficient ways of translating Japanese euphemisms into English.
\end{abstract}

Keywords: euphemisms, Japanese language, thematic fields, ways of making euphemisms, logical periphrasis, preterition, metaphor, metonymy, borrowed words, meiosis.

DOI: 10.17516/1997-1370-2015-8-9-1864-1876.

Research area: philology.

\section{Introduction}

It is hardly possible to surprise anyone saying that the Japanese are very polite. A lot of people would illustrate the statement with numerous examples of their extraordinary politeness either from their personal experience or from films, books, articles or stories they have heard from their friends and relatives who have visited Japan. Indeed, if we judge only by short personal contacts with Japanese culture, it is difficult to think in a different way and some might regret that they are not as polite as the Japanese are.

One of the reasons why foreigners are so amazed at how polite the Japanese are is that they always deal with their formal politeness or courtesy to others. However, in Japan there is often no place for formal politeness between family members, colleagues and friends: the language becomes less veiled and euphemisms sometimes give way to dysphemisms. Alpatov notes that the level and degree of politeness of the Japanese depends on many factors, for example, degree of familiarity (someone they know well (uchi) or not well (soto), one's social status (how high or low it is) and age (Alpatov, 2008:79-89; Alpatov, 2009: 16-20).

There is a great number of academics studying Japanese culture, language and

(c) Siberian Federal University. All rights reserved

* Corresponding author E-mail address: ofivanova@hse.ru, eanashkina@hse.ru 
politeness. Among the most prominent Russian scientists in these fields are N. Conrad (1966), S. Neverov (1982), A. Kholodovich (1979) and V. Alpatov (2004; 2009). Among modern Japanese theorists of courtesy are S. Ide (1989), E. Matsumoto (1988), M. Takekuro (2010) and many others.

\section{Theoretical framework \\ Politeness Theory and the Japanese Language}

One of the first academics to mention the phenomenon of politeness in 1973 was American linguist Robin Lakoff. According to her, politeness can be achieved by avoiding imposing one's opinion and letting the interlocutor have an option, as well as being friendly with them (1973). In 1978 politeness theory was first formulated by British scientists, Stephen Levinson and Penelope Brown. They published their work, "Politeness: Some Universals in Language Usage", which was devoted to language structures related to formality and politeness across the world (1987). Since then the notion of 'face' has become well known. They distinguish positive and negative faces (1987). The idea of the positive face is that people try to show themselves positively and to be evaluated favourably by their interlocutors. The idea of the negative face is that we try to protect ourselves from different kinds of impositions. Even though the theory has been largely approved, there are academics who do not agree with its universal character. Many of them think it is hard to apply this theory to some languages (for example, Japanese) as it is based on the values of Western countries (for example, individualism) (Matsumoto, 1988; Matsumoto, 1989; Haugh, 2005). In Japan protecting the face of a group is much more important than that of an individual (Matsumoto, 1988), as well as the concept of place means a lot (Haugh, 2005). Watts believes that the level of politeness should be considered not only from the speaker's point of view but from the point of view of the listener as only the latter can evaluate the level of politeness or impoliteness directed at him (Watts, 2003). According to him, one of the weak sides of the politeness theory is that it does not consider the phenomenon of impoliteness (Watts, 2003: 85). Larina assumes that the way the theory works in real life depends on the national specifics of interlocutors (Larina, 2009).

We believe that no matter whose face is protected (that is of an individual or a group, positive or negative), politeness will always be a guarantee of successful communication (personal, interpersonal, intrapersonal, etc.). One of the ways of achieving politeness is through euphemisms that soften, veil or hide even the ugliest truth. In addition, they can help avoid conflicts in communication and save interlocutors' faces. At the same time, an individual's choice of a language strategy and use of euphemistic lexis depends on their cultural values. This is an individual language strategy choice, not a universal character.

Japanese language and culture researchers rarely pay much attention to Japanese euphemisms, which is probably due to the fact that politeness in Japanese is often achieved via its grammar not lexis. Alpatov has mentioned this phenomenon in some of his works (2009). This paper does not aim to disagree, but we believe that the numerous Japanese euphemisms are worthy of more attention.

In this article, we would like to present the results of a pilot research conducted at Hokkaido University, Japan. The aim of the research was to collect euphemisms used by the Japanese in such thematic fields as low intelligence, physically challenged people, ugly appearance, serious diseases, death, and low social status, and also to find out the most frequent ways of 
making euphemisms. The choice of the thematic fields was based on the results of a research project conducted at Lomonosov Moscow State University in 2001-2004 (Ivanova, 2007). The thematic fields were among the most euphemized ones in the dictionaries analysed.

\section{Participants}

Eighty-seven Hokkaido University teachers, undergraduate and postgraduate students $\left(58 \mathrm{M}^{1}, 29 \mathrm{~F}\right)$ participated in the pilot research. Most of them were native speakers of Japanese (95\%) between 18 and 60. Also, there were four foreigners (a Singaporean, a Chinese, a Korean, and a Taiwanese), who spoke Japanese at a professional level. To make the analysis of the data easier the participants were divided into three age groups: 18-30, 3150 , and $51+$. The most numerous group was the first one, which had 70 people (46M, 24F). The second group (31-50 years old) consisted of 14 people $(9 \mathrm{M}, 5 \mathrm{~F})$, and the third group $(51+)$ was the smallest one with only three people $(2 \mathrm{M}$, $1 \mathrm{~F})$.

Forty-two participants were students $(27 \mathrm{M}$, $15 \mathrm{~F})$, thirty-six were graduate students $(24 \mathrm{M}$, $12 \mathrm{~F})$ and nine were teachers $(5 \mathrm{M}, 4 \mathrm{~F})$.

The participants could answer all the questions anonymously.

\section{Data Collection}

Alltheparticipantsansweredaquestionnaire, where the thematic fields of low intelligence, physically challenged people, ugly appearance, serious (incurable) diseases, death, and low social status were the focus. The participants answered the questions in the classrooms at the beginning of their classes. The teachers could answer the questions in their offices at a time they found convenient. The questions were in two languages - English (it is an obligatory subject at universities in Japan, and is referred as 'the first foreign language') and Japanese ${ }^{2}$ (to eliminate a possible misunderstanding of the questions. The participants wrote in both characters and hiragana/ katakana. They were asked to duplicate their answers in hiragana/ katakana to eliminate difficulties that might have occurred due to the peculiarities of their handwriting when the data were analysed. We specifically asked to write euphemistic words and phrases, because we were particularly interested in polite lexis not grammar. On average, it took the participants 20 minutes to answer the questions. There was not a single case of misunderstanding, refusal to participate in the research or any other difficulty.

The questionnaire consisted of the following questions:

1. How would you describe a person who is not very clever, when talking about them a) to your friend; b) to your teacher, and c) to someone you do not know well (e.g. a policeman, a journalist)?

Amari atama ga yokunai hito no koto o wadai ni suru toki, anata wa, ika no hitobito ni taishite, dono yooni sono hito no koto o setsumei shimasuka? (a. anata no yuujin; b. anata no sensei; c. amari yoku shiranai hito (keikan)?

2. You are talking about a disabled person. How would you describe them if you were talking about them to a) to your friend; b) to your teacher, and c) to someone you do not know well (e.g. a police officer, a journalist)?

Anata wa, shoogai no aru hito ni tsuite no hanashi o shite imasu. Sono hito no koto o, tsugi no hitobito ni taishite, dono yooni setsumei shimasu ka? (a. anata no yuujin; b. anata no sensei; c. amari yoku shiranai hito)?

3. You have just seen a movie, where the main actor/actress is not good-looking. How would you describe the actor/actress if you were asked by a) your friend; b) your 
teacher, and c) someone you do not know well (e.g. a police officer, a journalist)?

Anata wa eiga o mimashita ga, shujinkoo wa kirei dewa arimasen deshita. Tsugi no hitobito kara, shujinkoo ni tsuite kikaretara, dono yooni setsumei shimasu ka? (a. anata no yuujin; b. anata no sensei; c. amari yoku shiranai hito)?

4. One of your friend's father is seriously ill (cancer), that is why your friend is sometimes absent from university. How would you explain about the disease if you are asked by a) your friend; b) your teacher, and c) someone you do not know well (e.g. a police officer, a journalist)?

Anata no yuujin no chichioya ga omoi byooki (tatoeba, gan) no tame ni, tokidoki daigaku o yasunde imasu. Sono koto o tsugi no hitobito kara kikaretara, dono yooni sono byooki no koto o tsutaemasu ka? (a. anata no yuujin; b. anata no sensei; c. amari yoku shiranai hito)?

5. If one of your acquaintances (shiriai) died how would you explain about that to a) your friend; b) your teacher, and c) someone you do not know well (e.g. a police officer, a journalist)?

Moshi shiriai ga shindara, tsugi no hitobito ni, sono koto o dono yooni tsutaemasu ka? (a. anata no yuujin; b. anata no sensei; c. amari yoku shiranai hito)?

6. You are talking about someone with a low social status (e.g. a worker, a street cleaner, someone who has lost his/her job, etc.). How would you refer to that kind of person if you were talking about them to a) your friend; b) your teacher, and c) someone you do not know well (e.g. a police officer, a journalist)?

Anata wa, teishyootokusha ya shitsugyoosha ni tsuite hanashi o shite imasu. Anata ga karera no koto o wadai ni suru toki, karera no koto o dono yooni hyoogenshimasu ka? (a. anata no yuujin; b. anata no sensei; c. amari yoku shiranai hito)?

\section{Results}

We analysed the questionnaires in two stages. First, we analysed all the collected data (words, phrases, and sentences) and eliminated the lexis that could not be considered as euphemisms. Thus, we sorted out all those variants that sounded either too straightforward or too blunt if not rude.

Every time we handed out the questionnaires to the participants, we defined euphemisms (enkyokuhyogen in Japanese) as 'emotionally neutral words and phrases which are used instead of their synonymic words and phrases that are understood by the speaker as indecent, rude or tactless' (Arapova, 1990: 590). Second, we analysed every word, phrase and sentence in terms of who provided them, at what age, of what gender and status. Then we conducted a quantity and quality analysis of the data.

\section{Thematic Field 'Low Intelligence'}

The first question was:

How would you describe a person who is not very clever, when talking about them a) to your friend; b) to your teacher, and c) to someone you do not know well (e.g. a police officer, a journalist)?

Amari atama ga yokunai hito no koto o wadai ni suru toki, anata wa, ika no hitobito ni taishite, dono yooni sono hito no koto o setsumei shimasuka? (a. anata no yuujin; b. anata no sensei; c. amari yoku shiranai hito (keikan)?

The participants used a lot of too straightforward lexis (for instance, $b a k k a^{3}$ idiot.) Most of those who came up with these kind of words were undergraduate and graduate students at the age of 18-30. All of them mentioned that they would use words similar to bakka only if they talked to their equals (people of the same age and status), that is mostly with their friends. Among other words that we found not euphemistic and did not analyze were aho (idiot, usually used in 
Osaka, Kansai), tawake (idiot (obsolete), used to be typical for Nagoya), manuke (idiot), komatta chan (silly little thing), atama yowai (literally 'the head is weak'), amari atama ga yokunai (literally 'the brain is weak'), atama ga warui hito (literally 'a person whose head is weak'), atama no kaiten ga warui hito (literally 'a person whose head does not think well'), kashikokunai hito (literally 'a person who lacks any intelligence'), atama ga tarinai hito (literally 'a person with no intelligence'). These words and phrases can be used quite harmlessly provided the environment allows that (for example, when talking to people of the same age and status, and perhaps in absence of strangers, that is witnesses).

When talking to a friend the participants would describe a person who is not very clever with the help of the following ways of making euphemisms:

1. Preterition:

Ano hito. That person... (2M; 18-30; 1US, 1GS)

Otsumu ga chotto. Literally 'The head is a bit...' (1F; 51+; T)

Aitsu no sei de mata hidoi me ni atta.

'Because of him something has happened...' (1F; 31-50; GS)

Most of the participants widely use preterition as a way of making euphemisms ${ }^{4}$, and not only for this field. To soften their words the Japanese often do not need to say anything, they can use preterition 'hoping that their interlocutor will guess the word from the context' (Moskvin, 2007: 204), which in its turn lets them make their communication safe. Besides, they often use the adverb chotto (literally a bit, a little bit), or even more often they use both preterition and the adverb chotto. The adverb, context and a specific intonation help them hear the word that was not said, and let the speaker avoid using rude words: otsumu ga chotto... (the head is a little bit...).
2. Metalepsis, which is close to metonymy and is 'a way of describing a situation with the help of such situations and phenomena that in this or that way are associated with it'(Moskvin, 2007:175):

Asobinin A cheerful person (1F; 18-30; GS)

Kosei ga yutaka sugiru hito. A very original person (1M; 31-50; T)

3. Meiosis, which Moskvin defines as 'a substitute of a word with its synonym which has a weaker degree of intensity' (Moskvin, 2007:218). In the following example the statement is softened with the adverb chotto:

Chotto nibui hito. A bit silly person (1M; 18 30; GS)

In a conversation with a teacher, the participants would talk about a person who is not very clever with the help of the following ways of making euphemisms:

1. Preterition:

Ano hito. This person... (3M, 1F; 18-30, GS)

2. Metalepsis:

Asobu koto ga sukina node. (literally, he/she likes having fun... (1F, 18-30, US)

3. Meiosis:

Fumajime (literally a not serious, unstable (student) (1F, 18-30, GS)

4. Logical periphrasis (Moskvin, 2007:195).

Additional softening is achieved with the help of the adverbs amari and chotto (a little, a bit, a little bit):

...no bun ya ni akarukunai hito. He does not have knowledge in this field... (literally, there is no light...) (1F, 18-30, US)

Kawatta hito. A person who is different from others (1M, 18-30, 1GS; 1F, 31-50,T)

Chotto rikai ni jikan no kakaru hito. He needs a bit of time to understand... (1M, 31-50,T)

Amari ii hodo de wa nai. Not everything is good. (1M, 18-30, US) 
Amari seiseki ga yokunai. He does not study well. (literally, 'he does not have much success') (1M, 18-30, US)

When talking to a stranger the participants would use the following ways of making euphemisms:

1. Preterition:

Ano hito. This person... (1M, 1F; 18-30, GS)

Sukoshi nukete iru. Something is wrong... (1M, 18-30, US)

1. Logical periphrasis:

Jooshiki ga nai desu. There is no common sense... (He/ she cannot think deeply.) (1M, 18-30, US)

Chotto muzukashii ka mo shire masen. It is a bit difficult for him... $(1 \mathrm{~F}, 51+, \mathrm{T})$

1. Meiosis:

Sukoshi doryoku ga hitsuyoona tokoro ga arimasu. (He/she) needs to make every effort... (1M, 18-30, US)

Mo sukoshi oshiete hoshii... He needs to study more. (1M, 31-50, GS)

Amari seiseki no yokunai. He has not achieved much. (1M, 18-30, US)

Mono o shiranai no desu. Literally, he does not know much. (1F, 18-30, US)

The participants use the verb forms masu and desu as well as the adverb sukoshi to make their speech softer or more neutral.

\section{Thematic Field}

\section{'Physically Challenged People'}

The second question was:

You are talking about a disabled person. How would you describe them if you were talking about them to a) to your friend; b) to your teacher, and c) to someone you do not know well (e.g. a police officer, a journalist)?

Anata wa, shoogai no aru hito ni tsuite no hanashi o shite imasu. Sono hito no koto o, tsugi no hitobito ni taishite, dono yooni setsumei shimasu ka? (a. anata no yuujin; b. anata no sensei; c. amari yoku shiranai hito)?
In a conversation with a friend, the participants would use such ways of making euphemisms as:

1. Preterition:

Ano hito... This person... (1M., 18-30, US)

Chotto... A bit... (1 M, 18-30, US)

Chotto hito ni wa ienai jijoo ga aru. I cannot say what the matter is with him... (1M, 1830, US)

Kawaisoona hito da. I feel sorry for him... (1M, 1F; 18-30; 1US, 1GS)

2. Five out of eighty-seven respondents used borrowed words to soften their speech (the word handi is derived from the English word handicap):

Handi ga aru hito. He has a handicap (1M., $4 \mathrm{~F} ; 4$ of them - 18-30, $2 \mathrm{~F}-\mathrm{US}, 1 \mathrm{M}-\mathrm{GS}$, $1 \mathrm{~F}-\mathrm{T} ; 1$ of them is $51+; \mathrm{F}, \mathrm{T}$ )

3. When talking to a friend many of the participants would name the denotatum directly without using any soft forms:

Shoogai no aru hito. He has a handicap. (18M, 15F; 15M and 13F - 18-30, 2M, 2F $31-50,1 \mathrm{M}-51+; 8 \mathrm{M}, 8 \mathrm{~F}-\mathrm{US}, 8 \mathrm{M}, 7 \mathrm{~F}-\mathrm{GS}$, $2 \mathrm{M}-\mathrm{T})$

Karada no fujiyuuna hito. The body is not free... (4M, 4F - 18-30, 2F - 31-50; 2M, 2F US, $2 \mathrm{M}, 1 \mathrm{~F}-\mathrm{GS}, 1 \mathrm{~F}-\mathrm{T}$ )

When talking to a teacher the respondents would euphemize their speech with the following devices:

1. Preterition:

Ano hito... This person... (1M, 18-30, US)

Chotto... A bit... (1M, 18-30, US)

2. Meiosis:

Hito ni wa ienai koto ga arimasu. He has a small problem... (1M, 18-30, US)

3. Borrowed words:

Handikyappu o motte iru hito. He has a handicap. (1F, 18-30, GS)

Again, a considerable part of the respondents would prefer not to use euphemistic expressions: 
Shoogai no aru hito. He has an obstacle. (21M, 14F; 17M, 11F - 18-30, 3M, 3F - 31-50, $1 \mathrm{M}-51+$; $9 \mathrm{M} 6 \mathrm{~F}-\mathrm{US}, 9 \mathrm{M}, 7 \mathrm{~F}-\mathrm{GS}, 3 \mathrm{M}, 1 \mathrm{~F}-$ T)

Karada no fujiyuuna hito. The body is not free... (12M; 9F; 9M, 5F - 18-30, 3M, 3F - 31$50,1 \mathrm{~F}-51+; 5 \mathrm{M}, 5 \mathrm{~F}-\mathrm{US}, 6 \mathrm{M}, 2 \mathrm{~F}-\mathrm{GS}, 1 \mathrm{M}$, $2 \mathrm{~F}-\mathrm{T})$

Umaku karada ga ugokanai $n$ desu. He cannot move on his own. (1F, 18-30, US)

Though in the latter example the student would use a direct nomination, nevertheless she uses the link form desu to make her statement sound more polite when she talks to her teacher.

The data show that the male respondents would not opt for euphemistic lexis. Besides, most of those who would prefer to use more straightforward words (both men and women) are at the age between 18 and 30 .

When talking to a stranger the respondents would prefer to use the following ways of making euphemisms:

1. Preterition:

Ano hito... This person... (1M, 18-30, US)

Hito ni wa iinikui jijoo ga arimasu. I cannot say what (problem) he has... (1M, 18-30, US)

2. Some of the respondents would prefer to say as it is:

Shoogai no aru hito. He has an obstacle. (23M, 17F; 19M, 13F - 18-30, 3M, 3F - 31$50,1 \mathrm{M}, 1 \mathrm{~F}-51+; 11 \mathrm{M}, 7 \mathrm{~F}-\mathrm{US}, 9 \mathrm{M}, 9 \mathrm{~F}-$ GS; 3M, $1 \mathrm{~F}-\mathrm{T}$ )

Karada no fujiyuuna hito. The body is not free... (12M, 6F; 9M, 4F - 18-30, 3M, 2F $31-50,1 \mathrm{~F}-51+; 5 \mathrm{M}, 4 \mathrm{~F}-\mathrm{US}, 6 \mathrm{M}, 1 \mathrm{~F}-\mathrm{US}$, $1 \mathrm{M}, 1 \mathrm{~F}-\mathrm{T})$

Most of the young respondents irrespective of whom they would talk to about physically challenged people would prefer not to use euphemisms at all. More mature respondents (at the ages of 31-50, 51+) in most cases would prefer to use preterition.

\section{Thematic Field 'Ugly Appearance'}

The third question was:

You have just seen a movie, where the main actor/actress_is not good-looking. How would you describe the actor/actress if you were asked by a) your friend; b) your teacher, and c) someone you do not know well (e.g. a police officer, a journalist)?

Anata wa eiga o mimashita ga, shujinkoo wa kirei dewa arimasen deshita. Tsugi no hitobito kara, shujinkoo ni tsuite kikaretara, dono yooni setsumei shimasu ka? (a. anata no yuujin; b. anata no sensei; c. amari yoku shiranai hito)?

Talking to a friend the participants would use these ways of making euphemisms:

1. Metaphor:

Omoshiroi Interesting (appearance) (1F, 31$50,51+, \mathrm{T})$

2. Borrowed words:

Yuniiku Unique, unusual (1M, 31-50, T)

Some of the respondents would use direct lexis:

Busaiku Ugly, unattractive (17M, 11F; 15M, $7 \mathrm{~F}-18-30,2 \mathrm{M}, 4 \mathrm{~F}-31-50$; 9M, 5F - US, 6M, $4 \mathrm{~F}-\mathrm{GS}, 2 \mathrm{M}, 2 \mathrm{~F}-\mathrm{T}$ )

The word busaiku (ugly) is often used to describe a woman. The majority of those who would use the word are male respondents at the age of 18-30.

In a conversation with a teacher, most of the respondents (both male and female) would describe a not good-looking actor/ actress not with the help of polite words, but they would use such ways of softening their speech as the link word desu and the adverb amari:

Kakkoo warui desu... The appearance is not very... (7M, 1F; 5M - 18-30, 2M, $1 \mathrm{~F}-31-50$; $3 \mathrm{M}-\mathrm{US}, 2 \mathrm{M}-\mathrm{GS}, 2 \mathrm{M}, 1 \mathrm{~F}-\mathrm{T}$ ) 
Amari kirei de wa nai hito (not very beautiful) (16M, 8F; 15M, 8F - 18-30, 1M - 31$50 ; 12 \mathrm{M}, 6 \mathrm{~F}-\mathrm{US}, 4 \mathrm{M}, 2 \mathrm{~F}-\mathrm{GS})$

Amari kawaikunai hito. (Not a very handsome person.) (2M, 3F; $2 \mathrm{M}, 3 \mathrm{~F}-18-30 ; 1 \mathrm{M}$, $2 \mathrm{~F}-\mathrm{US}, 1 \mathrm{M}, 1 \mathrm{~F}-\mathrm{GS})$

Four male students would not try to be delicate and would call a not good-looking actress as busaiku that is ugly:

Busaiku (ugly) (4M; 3 - 18-30, 1 - 31-50; 3 US, 1 - GS)

If the respondents had to talk to a stranger about someone who is not good-looking, they would use:

1. Preterition:

Kare wa chotto... This person is a bit... (1M, 18-30, GS)

\section{Meiosis:}

Amari kirei de nai Not very beautiful (16M, $5 \mathrm{~F} ; 14 \mathrm{M}, 5 \mathrm{~F}-18-30,2 \mathrm{M}-31-50 ; 12 \mathrm{M}, 4 \mathrm{~F}-\mathrm{US}$, $3 \mathrm{M}, 1 \mathrm{~F}-\mathrm{GS}, 1 \mathrm{M}-\mathrm{T}$ )

Yosu ga amari yokunai. The appearance is not very good... (4M, $1 \mathrm{~F} ; 2 \mathrm{M}, 1 \mathrm{~F}-18-30,2 \mathrm{M}-$ 31-50; 1M, 1F - US, $1 \mathrm{M}-\mathrm{GS}, 2 \mathrm{M}-\mathrm{T}$ )

3. Four students would not use any euphemisms but describe such an actress as ugly:

Busaiku. Ugly (3M, 1F; 2M, 1F - 18-30, $1 \mathrm{M}-31-50 ; 1 \mathrm{M}$ - US, $1 \mathrm{M}, 1 \mathrm{~F}-\mathrm{GS})$

\section{Thematic Field 'Serious \\ (Incurable) Disease'}

The fourth question was:

One of your friend's father is seriously ill (cancer), that is why your friend is sometimes absent from university. How would you explain about the disease if you were asked by a) your friend; b) your teacher, and c) someone you do not know well (e.g. a police officer, a journalist)?

Anata no yuujin no chichioya ga omoi byooki (tatoeba, gan) no tame ni, tokidoki daigaku o yasunde imasu. Sono koto o tsugi no hitobito kara kikaretara, dono yooni sono byooki no koto o tsutaemasu ka? (a. anata no yuujin; b. anata no sensei; c. amari yoku shiranai hito)?

In a conversation with a friend some of the participants would use logical periphrasis as a way of euphemizing words that may hurt their friend:

Katei no jijoo de yasunde. Absent due to family reasons (3M, 18-30, 1 - US, 2 - GS)

Kazoku ga taihen. There are problems in his family. (1M, 1F; $2-31-50 ; 1 \mathrm{M}-\mathrm{GS}, 1 \mathrm{~F}-\mathrm{T}$ )

Kare no otoosan chotto taichyoo ga yokunai mitai da yo. His father's condition does not seem to be very good. (1M, 2F; 3 - 18-30; $1 \mathrm{M}, 1 \mathrm{~F}-\mathrm{US} ; 1 \mathrm{~F}-\mathrm{GS}$ )

Most of the respondents would not use any euphemisms at all; instead, they would soften their phrases with such grammar means as link words desu and rashii:

Otoosan no chooshi ga warui rashii. It seems that his father's condition is not very good. (2M, $1 \mathrm{~F} ; 2-31-50 ; 1 \mathrm{M}-\mathrm{GS}, 1 \mathrm{M}$, $1 \mathrm{~F}-\mathrm{T})$

Otoosan no guai ga yokunai rashii. It seems that his father does not feel very well. (2M, 1F; 3 - 18-30; $1 \mathrm{~F}$ - US; $1 \mathrm{M}$ - GS; $1 \mathrm{M}$ - T)

Kare no otoosan byooki rashii. It seems his father is sick. (6M, $2 \mathrm{~F} ; 4 \mathrm{M}, 2 \mathrm{~F}-18-30,2 \mathrm{M}-31-$ 50; 1F - US, 6M, 1F - GS)

Otoosan ga omoi byooki desu. His father is seriously sick. (14M, 14F; 11M, 12F - 18-30, 2M, $1 \mathrm{~F}-31-50,1 \mathrm{M}, 1 \mathrm{~F}-51+; 8 \mathrm{M}, 9 \mathrm{~F}-\mathrm{US}, 3 \mathrm{M}$., $6 \mathrm{~F}-$ GS, $3 \mathrm{M}-\mathrm{T}$ )

In a conversation with a teacher, the respondents would use these ways of making euphemisms:

\section{Logical periphrasis:}

Katei no jijoo de yasunde. Absent due to family reasons. (3M, 3F; 3M $2 \mathrm{~F}-18-30,1 \mathrm{~F}-31-$ $50 ; 2 \mathrm{M} 1 \mathrm{~F}-\mathrm{US} ; 1 \mathrm{M} 1 \mathrm{~F}-\mathrm{GS} ; 1 \mathrm{~F}-\mathrm{T}$ ) 
2. Also, they would soften their utterances with the help of the link word desu and the prefix go (gokazoku):

Otoosan ga omoi byooki desu. (His) father is seriously ill. (5M, 3F; 4M 3F - 18-30, $1 \mathrm{M}-51+$; $2 \mathrm{M} 3 \mathrm{~F}-\mathrm{US}, 2 \mathrm{M} 2 \mathrm{~F}-\mathrm{GS}, 1 \mathrm{M}-\mathrm{T}$ )

Gokazoku ga byooki rashii desu. It seems that someone in his family is seriously ill. (4M, 4F; 4M 3F - 18-30; $1 \mathrm{~F}-31-50 ; 1 \mathrm{M} 1 \mathrm{~F}-\mathrm{US}, 3 \mathrm{M}$ $2 \mathrm{~F}-\mathrm{GS}, 1 \mathrm{~F}-\mathrm{T}$ )

When talking to a stranger the respondents would talk about a serious disease in the family of their friend with the help of:

Logical periphrasis:

Katei no jijoo de yasunde. Absent due to family reasons. $(10 \mathrm{M}, 4 \mathrm{~F} ; 7 \mathrm{M}, 1 \mathrm{~F}-18-30,3 \mathrm{M}$, $3 \mathrm{~F}-31-50,4 \mathrm{M}-\mathrm{US}, 5 \mathrm{M}, 3 \mathrm{~F}-\mathrm{GS}, 1 \mathrm{M}, 1 \mathrm{~F}-\mathrm{T}$ )

Gokazoku no guai ga yokunai soo desu. It seems that in his family there is a difficult situation. (3M, 2F; 1 $\mathrm{M}, 2 \mathrm{~F}-18-30,2 \mathrm{M}-31-50$; $2 \mathrm{~F}-\mathrm{US}, 2 \mathrm{M}-\mathrm{GS}, 1 \mathrm{M}-\mathrm{T}$ )

In this example the statement also sounds softer and more polite due to the use of the honorific prefix $g o$.

Chichi no taichyoo ga sugure nai. Literally, his father's condition is not perfect. $(5 \mathrm{M}, 2 \mathrm{~F} ; 3 \mathrm{M}$, $2 \mathrm{~F}-18-30,2 \mathrm{M}-31-50 ; 2 \mathrm{M}, 1 \mathrm{~F}-\mathrm{US}, 1 \mathrm{M}, 1 \mathrm{~F}-$ GS, $2 \mathrm{M}-\mathrm{T}$ )

Many of the respondents would talk about a serious disease in their friend's family directly softening their words only with the help of link word desu (neutral politeness):

Otoosan ga omoi byooki desu. His father is seriously ill. $(6 \mathrm{M}, 3 \mathrm{~F} ; 5 \mathrm{M}, 2 \mathrm{~F}-18-30,1 \mathrm{M}, 1 \mathrm{~F}-$ $51+; 3 \mathrm{M}, 3 \mathrm{~F}-\mathrm{US}, 2 \mathrm{M}-\mathrm{GS}, 1 \mathrm{M}-\mathrm{T}$ )

Otoosan ga jyuubyoo nan desu. His father is seriously ill. $(3 \mathrm{M}, 3 \mathrm{~F} ; 2 \mathrm{M}, 2 \mathrm{~F}-18-30,1 \mathrm{M}$, $1 \mathrm{~F}-31-50 ; 1 \mathrm{M}, 1 \mathrm{~F}-\mathrm{US}, 1 \mathrm{M}, 1 \mathrm{~F}-\mathrm{GS}, 1 \mathrm{M}$, $1 \mathrm{~F}-\mathrm{T})$

\section{Thematic Field 'Death'}

The fifth question was the following one:
If one of your acquaintances (shiriai) died how would you explain about that to a) your friend; b) your teacher, and c) someone you do not know well (e.g. a police officer, a journalist)?

Moshi shiriai ga shindara, tsugi no hitobito ni, sono koto o dono yooni tsutaemasu ka? (a. anata no yuujin; b. anata no sensei; c. amari yoku shiranai hito)?

If the respondents had to talk about their acquaintance's death to their friend, they would use such ways of making euphemisms as:

1. Logical periphrasis:

Itte shimatta. He has gone. (2M, $1 \mathrm{~F}-18-30$, 1-31-50; 1- US, 1 - T)

Moo nido to au koto wa dekinai. We will never see each other again. (1M, 18-30, US)

Fukoo ga arimashita. A misfortune has happened. (2M, 1F; 3 - 18-30; $1 \mathrm{M}$ - US, 1M, 1F GS)

2. Metaphor:

Ten ni mesareta. He was asked to go to the heavens. (5M, 3F, 5M, 3F - 18-30; 5M, $1 \mathrm{~F}-\mathrm{US}$, $2 \mathrm{~F}-\mathrm{GS})$

Some of the respondents would prefer to use direct nomination of death:

Shiriai ga nakunatta. My acquaintance has died. (18M, 21F; 14M, 16F - 18-30, 4M, 4F - 31$50,1 \mathrm{~F}-51+; 5 \mathrm{M}, 9 \mathrm{~F}-\mathrm{US}, 11 \mathrm{M}, 9 \mathrm{~F}-\mathrm{GS}, 2 \mathrm{M}$, $3 \mathrm{~F}-\mathrm{T})$

To soften their statements in a conversation with a teacher the respondents would use:

1. Logical periphrasis:

Shiriai ni fukoo ga arimashita. A misfortune has happened to an acquaintance of mine. (4M, $3 \mathrm{~F} ; 2 \mathrm{M}, 3 \mathrm{~F}-18-30,2 \mathrm{M}-31-50 ; 2 \mathrm{M}, 1 \mathrm{~F}-\mathrm{US}$, $2 \mathrm{~F}-\mathrm{GS}, 2 \mathrm{M}-\mathrm{T}$ )

Moo au kotoga dekimasen. We will never be able to meet again. (1M, 18-30, GS)

\section{Metaphor:}

Takai shimashita. He has departed to another world. (1 M, 18-30, GS) 
Most of the respondents would use grammar means to make their utterances sound more neutral, for example, they would use the full (not shortened) form of the past tense:

Chijin ga nakunarimashita. An acquaintance has passed away. (43M, 24F, 36M, 18F - 18-30, $6 \mathrm{M}, 5 \mathrm{~F}-31-50,1 \mathrm{M}, 1 \mathrm{~F}-51+; 19 \mathrm{M}, 13 \mathrm{~F}-\mathrm{US}$, 20M, 7F - GS, 4M, 4F - T)

In a conversation to a stranger the respondents would use:

1. Logical periphrasis:

Fukoo ga arimashita. A misfortune has happened. (3M, 3F; 2M, 3F - 18-30, 1M - 31-50; $2 \mathrm{M}, 2 \mathrm{~F}-\mathrm{US}, 1 \mathrm{M}, 1 \mathrm{~F}-\mathrm{GS})$

Moo hanashitakutemo hanasu koto ga dekimasen. Even if I wanted to talk to him, I could not do that. (1M, 18-30, US)

\section{Metaphor:}

Takai shimatta. He has gone to another world. (2M, 1F; 1M, 1F - 18-30, 1M - 31-50; 1F US, $1 \mathrm{M}-\mathrm{GS}, 1 \mathrm{M}-\mathrm{T}$ )

Most of the respondents would use direct nomination:

Chijin/ shiriai ga nakunarimashita. My acquaintance has died. (39M, 21F; 33M, 17F - 18$30,6 \mathrm{M}, 3 \mathrm{~F}-31-50,1 \mathrm{~F}-51+; 17 \mathrm{M}, 12 \mathrm{~F}-\mathrm{US}$, $18 \mathrm{M}, 6 \mathrm{~F}-\mathrm{GS}, 4 \mathrm{M}, 3 \mathrm{~F}-\mathrm{T})$

\section{Thematic Field 'Low Social Status'}

The sixth question was:

You are talking about someone with a low social status (E.g. a worker, a street cleaner, someone who has lost his/her job, etc.) How would you refer to that kind of person if you were talking about them to a) your friend; b) your teacher, and c) someone you do not know well (e.g. a police officer, a journalist)?

Anata wa, teishyootokusha ya shitsugyoosha ni tsuite hanashi o shite imasu. Anata ga karera no koto o wadai ni suru toki, karera no koto o dono yooni hyoogenshimasu ka? (a. anata no yuujin; b. anata no sensei; c. amari yoku shiranai hito)?
Talking to a friend, the respondents would use:

1. Logical periphrasis:

Seikatsu ga taihenna hito. (It is) a person whose life is complicated. $(6 \mathrm{M}, 4 \mathrm{~F} ; 6 \mathrm{M}, 1 \mathrm{~F}-18$ $30,2 \mathrm{~F}-31-50,1 \mathrm{~F}-51+; 1 \mathrm{M}, 2 \mathrm{~F}-\mathrm{US}, 5 \mathrm{M}-\mathrm{GS}$, $2 \mathrm{~F}-\mathrm{T}$ )

Shigoto o sagashite iru. (He) is looking for a job. $(1 \mathrm{~F}, 31-50, \mathrm{~T})$

Komatte iru hitotachi. (They are) people who have problems. (2F, $1-18-30,1-51+, 1 \mathrm{US}, 1 \mathrm{~T})$

2. Borrowed words:

Furiita $^{5}$ A derived word from two borrowed words - free and arbeiter "worker" (German) (1M, 3F; 18-30; 3F - US, 1M - GS)

In a conversation with a teacher, the respondents would use such ways of euphemizing their speech as:

1. Logical periphrasis:

Seikatsu ga taihenna hito. A person whose life is complicated. (2M, 3F; $2 \mathrm{M}, 3 \mathrm{~F}-18-30 ; 2 \mathrm{M}$, $1 \mathrm{~F}-\mathrm{US}, 2 \mathrm{~F}-\mathrm{GS})$

Komatte iru hitotachi. People with problems (2F; 51+; 1US, 1T)

2. Borrowed words:

Furiita Furita (a young unemployed person at the age of 15-35) (1F, 31-50, GS)

When talking to a stranger most of the respondents would use logical periphrasis as the way of making euphemisms:

Seikatsu ga taihenna hito. A person with a complicated life. (3M, 2F; 2M, $1 \mathrm{~F}-18-30,1 \mathrm{M}-$ $31-50,1 \mathrm{~F}-51+; 2 \mathrm{M}, 2 \mathrm{~F}-\mathrm{US}, 1 \mathrm{M}-\mathrm{T}$ )

Kono saki ga shinpaina kata. I am worried about his future. (1M, 18-30, US)

Kyuushokuchuu no hito. A person who is looking for a job. (1M, 18-30, US)

\section{Conclusion}

As the research has been a pilot one all the conclusions should be considered as provisional ones that is the results of the present research can 
become a basis for the following more profound research. When we call the research a pilot one, we mean not only the number of the informants but also the fact that all of them are the Japanese studying and working at university. Those who work in other fields have not participated in the pilot research. Moreover, most of the respondents are students who have very little social experience or teachers for whom the main communicative environment has always been the same one - first they studied at university then they started working at university. ${ }^{6}$. We think this is one of the reasons why the respondents have often used quite straightforward lexis and why they have not made much difference between the addressees (a friend, a teacher, or a stranger).

According to the results the most frequently used ways of making Japanese euphemisms are preterition, logical periphrasis, meiosis, borrowed words and metaphor.

The data show that one of the unique features of the Japanese language is the ability to say something very politely not only with the help of euphemisms but also with the help of grammatical means such as link words, honorific prefixes, the full form of the predicate, expressed by a verb. (Alpatov, 2008: 79-89; Alpatov, 2008: 118-135; Alpatov, 2009; $16-20)$.
Sometimes the respondents left some of the questions unanswered. That may have happened because they were asked to think of some imaginary situations. The respondents had some time (quite a few minutes but still enough) to consider different variants of words and phrases that they could use in this or that situation. There was no spontaneity of speech. We assume in a real or in a more personally oriented situation, ${ }^{7}$ the respondents would come up with more varied answers. Despite the fact that the questionnaire was anonymous, still all the respondents seemed to be aware of the researcher's presence. For many of the respondents the researcher was also their teacher. We think all these facts may have influenced the results of the research.

On the other hand, the objectives of the pilot research have been achieved - the questionnaire was tested and its weaknesses were revealed. Further a more detailed research could be conducted on these thematic fields, either collecting lexical data from spoken Japanese (e.g. via arranging role-plays or using the method of biographic interviews), or collecting lexical data from newspapers, magazines, books and films.

Finally, in this research we have collected only the speaker's possible phrases. It could be interesting to analyse euphemisms collected in dialogues.

\footnotetext{
In this text the following contractions have been used: M (male), F (female); 18-30 (the age group of 18-30-year-old participants), 31-50 (the middle-aged group of 31-50 years old), 51+ (the age group of those who are more than 51 year old); US - undergraduate students, GS - graduate students, T - teachers.

Ms Maiko Aoki, a PhD and an Associate Professor at Hokkaido University, Japan has kindly done the translation.

3 I do apologize for having to use such impolite words and phrases. This is only due to the specific character of this research.

4 At present, there are quite a few classifications of the ways of making euphemisms. Among the most well-known ones are the ones elaborated by B. Larin, L. Bulakhovskiy, A. Reformatskiy, B. Tomashevskiy, S. Vidlak, L. Krisin, V. Moskvin, J. Neaman and C. Silver. B. Moskvin's classification is one of the most convincing and well-elaborated ones.

$5 \quad$ Furita are young people usually at the age between 18 and 35 years old without a permanent job. The term dates back to the 1990s when young people chose not to work in conservative Japanese companies, preferred to enjoy their lives, and postponed their careers for a later period. At present, the image of a furita is not so romantic. Now the reason for being a furita is often the fact that university graduates cannot find a good permanent job. In Japan, they say that if one has not found a good job before he or she is 30-35 years old, he or she will never find one. (Nihon de wa, 30-35 sai made ni (ii tokoro ni) shuushoku dekinakereba ishooshuushoku dekinai to iu)...

6 One of the Japanese colleagues working at Hokkaido University has once said that students are too young to be able to use polite lexis skilfully and some of their teachers have not learnt to use polite words as they have first studied and then
} 
continued working in the same environment, and as a result they often sound too straightforward even when they make a speech publicly.

We hope we have managed to ask the questions in such a way that the respondents' possible uncomfortable feelings have been minimized. Although more personally oriented questions might have given more varied answers.

\section{References}

1. Alpatov, V. The categories of politeness in contemporary Japanese [Kategorii vezhlivosti $v$ sovremennom yaponskom yazyke]. Moscow: LIBROKOM, 2009.

2. Alpatov, V. Japan: language and culture [Yaponiya: Yazyk i kul'tura]. Moscow: Yazyki slavyanskikh kul'tur (Studia philologica), 2008.

3. Alpatov, V. Language and society [Yazyk i obshchestvo]. Moscow: Muravey, 2004.

4. Arapova, N. (1990). Euphemisms [Evfemizmy] Lingvisticheskiy entsiklopedicheskiy slovar'. Moscow: Sovetskaya entsiklopediya, p.590.

5. Gorodetskaya, L. (2000). The universal theory of politeness and its meaning for comparative culture studies [Universal'naya teoriya vezhlivosti i ee znachenie dlya sopostavitel'noy kul'turol. ogii]. Diskussionnyy klub FLT. Intercultural communication: theory and practice, Moscow, 104128.

6. Ivanova, O. Euphemistic lexical units in English: how to sound nicely, politely and convincingly without lying [Evfemisticheskaya leksika angliyskogo yazyka: kak prozvuchat' krasivo, vezhlivo $i$ ubeditel'no i pri etom ne solgat]. Moscow: Maks-Press, 2007.

7. Konrad, N. West and East: Articles [Zapad i Vostok: Stat'i]. Moscow: Nauka, 1966.

8. Larina T.V. Categories of politeness and communication style: comparison of English and Russian lingucultural traditions [Kategoriya vezhlivosti i stil' kommunikatsii: sopostavlenie angliyskikh i russkikh lingvokul'turnykh traditsiy]. Moscow: Rukopisnye pamyatniki Drevney Rusi, 2009.

9. Moskvin V.P. Euphemisms in the lexical system of contemporary Russian [Evfemizmy $v$ leksicheskoy sisteme sovremennogo russkogo yazyka]. Moscow:URSS, 2007.

10. Neverov S.V. Obshchestvenno-yazykovaya praktika sovremennoy Yaponii. Moscow: KomKniga, 2005.

11. Polivanov E.D. Vvedenievyazykoznanie (dlya vostokovednykh vuzov). Seriya: Lingvisticheskoe nasledie XXveka / [Nauch. izd.]. Moscow: URSS, 2002.

12. Kholodovich A.A. Problemy grammaticheskoy teorii. Leningrad: Nauka, 1979.

13. Brown, P. and Levinson S. Politeness: Some Universals in Language Usage. Cambridge: Cambridge University Press, 1987.

14. Haugh, M. (2005). The importance of 'place' in Japanese politeness: Implications for crosscultural and intercultural analyses. Intercultural Pragmatics 2 (1), 41-68.

15. Ide, S. (1989). Formal forms and discernment: two neglected aspects of universals of linguistic politeness. Multilingua, 8(2/3): 223-248.

16. Lakoff, R. (1973). The logic of politeness; or, minding your p's and q's. Papers from the 9th Regional Meeting of the Chicago Linguistic Society, Chicago, Illinois, 292-305.

17. Matsumoto, Y. (1988). Reexamination of the universality of face: Politeness phenomena in Japanese. Journal of Pragmatics, 12, 403-426.

18. Matsumoto, Y. (1989). Politeness and conversational universals - Observations from Japanese. Multilingua, 8, 2/3, $207-221$. 
19. Takekuro, M. (2010). Collaborative Use of Honorifics in Japanese Interaction: An Example of a Breaching Experiment. The Waseda University Law Association Humanitas 48, 194-166.

20. Watts, R. J. Politeness. Cambridge: Cambridge University Press, 2003.

\section{Эвфемизмы в японском языке: \\ результаты исследования \\ некоторых тематических полей}

О.Ф. Иванова, Е.В. Анашкина

Высшая школа экономики

Москва, 101000, ул. Мясницккая, 20

На данный момент японские эвфемизмы продолжают оставаться недостаточно изученной темой. В данной статье приводятся результаты пилотного исследования японских эвфемизмов, проведенного в Университете Хоккайдо, Япония. На основе материала пилотного исследования, проведенного среди преподавателей, аспирантов и студентов, авторы выделяют наиболее типичные способы образования эвфемизмов в японском языке. Среди них логическое перефразирование, умолчание, меойзис, метонимия, метафора, а также заимствованные слова.

Ключевые слова: эвфемизмы, японский язык, тематические поля, способы образования эвфемизмов, логический перифраз, умолчание, метафора, метонимия, заимствованнье слова, мейозис.

Научная специальность: 10.00.00 - филологические науки. 